DOI $10.31489 / 2021 \mathrm{M} 2 / 74-83$

MSC 34B37, 37C25, 37C75

\author{
M.J. Mardanov ${ }^{1,2}$, R.S. Mammadov ${ }^{3}$, S.Yu. Gasimov ${ }^{3}$, Ya.A. Sharifov ${ }^{1,2, *}$ \\ ${ }^{1}$ Institute of Mathematics and Mechanics, Azerbaijan National Academy of Sciences, Baku, Azerbaijan; \\ ${ }^{2}$ Baku State University, Azerbaijan; \\ ${ }^{3}$ Azerbaijan State University of Oil and Industry, Baku, Azerbaijan \\ (E-mail: misirmardanov@yahoo.com,rasadmammedov@gmail.com,sardarkasumov1955@mail.ru, \\ sharifov22@rambler.ru)
}

\title{
Existence and uniqueness results for the first-order non-linear impulsive integro-differential equations with two-point boundary conditions
}

\begin{abstract}
The article discusses the existence and uniqueness of solutions for a system of nonlinear integro-differential equations of the first order with two-point boundary conditions. The Green function is constructed, and the problem under consideration is reduced to equivalent integral equation. Existence and uniqueness of a solution to this problem is analyzed using the Banach contraction mapping principle. Schaefer's fixed point theorem is used to prove the existence of solutions.
\end{abstract}

Keywords: two-point boundary conditions, impulsive systems, existence and uniqueness solutions, fixed point theorems, first order differential equation.

\section{Introduction}

A lot of problems of physics, engineering, biology and economy are described by differential and integrodifferential equations. Such differential equations were studied rather well in [1-8]. In the above mentioned papers mainly the differential equations with local conditions are studied. However, in the last years there is a great interest to differential and integro-differential equations with nonlocal boundary conditions, by which a number of practical processes are described. Today, there exist a great number of works devoted to ordinary differential and integro-differential equations with nonlocal boundary conditions in which the theorem on the existence of solutions are proved for different types of nonlocal conditions [9-20].

Note that numerical methods for multipoint and integral boundary problems for first-order ordinary differential equations were developed in [21, 22].

It should be noted that the authors know about the study of boundary value problem as the form of

$$
\left\{\begin{array}{c}
\dot{x}(t)=f(t, x(t)), t \in[0, T] \\
A x(0)+B x(T)=C
\end{array}\right.
$$

from [23, 24], where $A, B \in R^{n \times n}$ are given matrices, $f \in R^{n}$ is a given function and it is assumed that the condition $\operatorname{det} B \neq 0$ is satisfied. An approximate solution of the problem (1) was constructed using a numericalanalytical method developed by Samoilenko with the given initial conditions. In [11] the boundary value problem was investigated as follows:

$$
\left\{\begin{array}{c}
\dot{x}(t)=f(t, x(t)), t \in[0, T], t \neq t_{i}, i=1,2, \ldots, p \\
A x(0)+B x(T)=C \\
\Delta x\left(t_{i}\right)=I_{i}\left(x\left(t_{i}\right)\right), i=1,2, \ldots, p .
\end{array}\right.
$$

Here $A, B \in R^{n \times n}$ are given matrices, $f, I_{i} \in R^{n}, i=1,2, \ldots, p$ are given functions and $\operatorname{det}(A+B) \neq 0$. Theorems on the existence and uniqueness of the solution of the boundary value problem (2) under suitable conditions have been proved. In this article the generalization of the boundary value problem (2) for the Volterra-Fredholm type system of integro-differential equations with two-point and impulse effect is studied.

\footnotetext{
${ }^{*}$ Corresponding author.

E-mail: sharifov22@rambler.ru
} 


\section{Problem statement}

In this paper we study the existence and uniqueness of solutions of nonlinear integro-differential equations of the type

$$
\dot{x}=f(t, x, \phi x(t), \varphi x(t)), \quad t \in[0, T], t \neq t_{i}, \quad i=1,2, \ldots p
$$

with two-point boundary conditions

$$
A x(0)+B x(T)=\alpha
$$

and impulsive conditions

$$
\Delta x\left(t_{i}\right)=I_{i}\left(x\left(t_{i}\right)\right), \quad i=1,2, \ldots, p, 0=t_{0}<t_{1}<\ldots<t_{p}<T_{p+1}=T
$$

where $A$ and $B$ are constant square matrices of order $n$ such that $\operatorname{det} N \neq 0, N=A+B ; f:[0, T] \times R^{n} \times R^{n} \times$ $\times R^{n} \rightarrow R^{n}$ and $I_{i}: R^{n} \rightarrow R^{n}, i=1,2, \ldots, p$ are a given function and

$\phi x(t)=\int_{0}^{t} \mu(t, s) x(s) d s, \varphi x(t)=\int_{0}^{T} \gamma(t, s) x(s) d s$, where $\mu, \gamma: R \times R \rightarrow R^{n \times n}$

with $\phi_{0}=\max _{t, s \in[0 T]}\|\phi(t, s)\|<\infty, \gamma_{0}=\max _{t, s \in[0, T]}\|\gamma(t, s)\|<\infty$,

$$
\Delta x\left(t_{i}\right)=x\left(t_{i}^{+}\right)-x\left(t_{i}\right), \quad i=1,2, \ldots, p
$$

where

$$
x\left(t_{i}^{+}\right)=\lim _{h \rightarrow 0^{+}} x\left(t_{i}+h\right), x\left(t_{i}^{-}\right)=\lim _{h \rightarrow 0^{-}} x\left(t_{i}+h\right)
$$

are the right-hand and left-hand limits of $x(t))$ at $t=t_{i}$, respectively.

In this work for the Green function is constructed for the two-point boundary value problem and the considered problem is reduced to the equivalent integral equations. Then the existence and uniqueness of the solutions is studied using the Banach contraction mapping principle. The existence of the solution is also proved by applying Schaefer's fixed point theorem.

This paper is organized as follows. In Section 2, we introduce definition and lemmas, which are the key tools for our main result. Section 3 focuses the theorems on the existence and uniqueness of the solution of problem (3)-(5) established under some sufficient conditions on the nonlinear terms. An example is included.

\section{Preliminaries}

In this section we present some basic definitions and preliminary facts which are used throughout the paper. We denote by $C\left([0, T] ; R^{n}\right)$ the Banach space of all continuous functions from $[0, T]$ into $R^{n}$ with the norm

$$
\|x\|=\max \{|x(t)|: t \in[0, T]\}
$$

where $|\cdot|$ is the norm in the space $R^{n}$.

We define the linear space

$$
\begin{aligned}
& P C\left([0, T] ; R^{n}\right)=\left\{x:[0, T] \rightarrow R^{n} ; x(t) \in C\left(\left(t_{i}, t_{i+1}\right] ; R^{n}\right), i=1,2, \ldots, p,\right. \\
& \left.x\left(t_{i}^{-}\right) \text {and } x\left(t_{i}^{+}\right) \text {exist, } i=0,1, \ldots, p \text { and } x\left(t_{i}^{-}\right)=x\left(t_{i}\right)\right\} .
\end{aligned}
$$

Obviously, $P C\left([0, T] ; R^{n}\right)$ is a Banach space with norm

$$
\|x\|_{P C}=\max \left\{\|x\|_{\left(t_{i}, t_{i+1}\right]}, i=0,1, \ldots, p\right\} .
$$

For the sake of simplicity, we can consider the following problem:

$$
\begin{gathered}
\dot{x}(t)=y(t), \quad t \in[0, T], \\
A x(0)+B x(T)=\alpha, \\
\Delta x\left(t_{i}\right)=a_{i}, \quad i=1,2, \ldots, p .
\end{gathered}
$$

Lemma 1. Let $y \in C\left([0, T] ; R^{n}\right)$ and $a_{i} \in R^{n}$. The unique solution $x(t) \in P C\left([0, T] ; R^{n}\right)$ of the boundary value problem for differential equation (6) with boundary conditions (7) and impulsive conditions (8) is given by 


$$
x(t)=N^{-1} \alpha+\int_{0}^{T} G(t, \tau) y(\tau) d \tau+\sum_{0<t_{k}<T} G\left(t_{i}, t_{k}\right) a_{k}
$$

for $t \in\left(t_{i}, t_{i+1}\right], i=0,1, \ldots, p$, where

$$
G(t, \tau)=\left\{\begin{array}{c}
N^{-1} A, \quad 0 \leq \tau \leq t \\
-N^{-1} B, \quad t<\tau \leq T .
\end{array}\right.
$$

Proof. If function $x=x(\cdot)$ is a solution of the differential equation (6), then for $t \in(0, T)$

$$
\begin{gathered}
\int_{0}^{t} y(s) d s=\int_{0}^{t} \dot{x}(s) d s=\left[x\left(t_{1}\right)-x\left(0^{+}\right)\right]+\left[x\left(t_{2}\right)-x\left(t_{1}{ }^{+}\right)\right]+\ldots+\left[x(t)-x\left(t_{i}{ }^{+}\right)\right] \\
=-x(0)-\left[x\left(t_{1}^{+}\right)-x\left(t_{1}\right)\right]-\left[x\left(t_{2}^{+}\right)-x\left(t_{2}\right)\right]-\ldots-\left[x\left(t_{i}^{+}\right)-x\left(t_{i}\right)\right]+x(t)
\end{gathered}
$$

where $x_{0}$ is an arbitrary constant vector. Using this formula and condition (8), we can write

$$
x(t)=x(0)+\int_{0}^{t} y(s) d s+\sum_{0<t_{i}<t} a_{i} .
$$

Now we define $\mathrm{x}_{0}$ so that the function in equality (10) satisfies condition (7). Then we have

$$
(A+B) x(0)=\alpha-B \int_{0}^{T} y(t) d t-B \sum_{0<t_{k}<T} a_{k} .
$$

This obviously implies

$$
x_{0}=N^{-1} \alpha-N^{-1} B \int_{0}^{T} y(\tau) d \tau-N^{-1} B \sum_{0<t_{k}<T} a_{k} .
$$

Now in (8) we take into account the value $x_{0}$ determined from the equality (11) and yield

$$
x(t)=N^{-1} \alpha-N^{-1} B \int_{0}^{T} y(\tau) d \tau-N^{-1} B \sum_{0<t_{k}<T} a_{k}+\int_{0}^{t} y(s) d s+\sum_{0<t_{i}<t} a_{i} .
$$

Since equality

$$
\left(E-N^{-1} B\right)=N^{-1} A
$$

is true, then we can introduce the following function:

$$
G(t, \tau)=\left\{\begin{array}{c}
N^{-1} A, \quad 0 \leq \tau \leq t \\
-N^{-1} B, \quad t<\tau \leq T .
\end{array}\right.
$$

Using this function, equality (12) can be written as an impulsive integral equation (9).

Lemma 2. Assume that $f \in C\left([0, T] \times R^{n} ; R^{n}\right)$. Then the function $x(t)$ is a solution of boundary-value problem (3)-(5) if and only if $x(t)$ is a solution of the impulsive integral equation

$$
x(t)=N^{-1} \alpha+\int_{0}^{T} G(t, \tau) f(\tau, x(\tau), \phi x(\tau), \varphi x(\tau)) d \tau+\sum_{0<t_{i}<T} G\left(t_{i}, t_{k}\right) I_{k}\left(x\left(t_{k}\right)\right) .
$$

Proof. Let $x(t)$ be a solution of the boundary value problem (3)-(5). This lemma can be derived by a similar argument to Lemma 1. By checking directly, we make sure that the solution of integral equation (13) satisfies the boundary value problem (3)-(5). Lemma 2 is proved. 


\section{Main results}

We introduce the following conditions:

(H1) The functions $f:[0, T] \times R^{n} \times R^{n} \times R^{n} \rightarrow R^{n}$ and $I_{i}: R^{n} \rightarrow R^{n} i=1,2, \ldots, p$ are continuous;

(H2) There exist a constants $M \geq 0$ and $l_{i} \geq 0, i=1,2, \ldots, p$ such that

$$
\begin{gathered}
\left|f\left(t, x_{1}, x_{2}, x_{3}\right)-f\left(t, y_{1}, y_{2}, y_{3}\right)\right| \leq M\left(\left|x_{1}-y_{1}\right|+\left|x_{2}-y_{2}\right|+\left|x_{3}-y_{3}\right|\right), \\
\left|I_{i}\left(x_{1}\right)-I_{i}\left(y_{1}\right)\right| \leq l_{i}\left|x_{1}-y_{1}\right|, i=1,2, \ldots, p
\end{gathered}
$$

for each $t \in[0, T]$ and all $x_{1}, x_{2}, x_{3}, y_{1}, y_{2}, y_{3} \in R^{n}$;

(H3) There exists a constants $K, k$ such that $|f(t, x)| \leq K,\left|J_{i}(x)\right| \leq k, i=1,2, \ldots, p$ for each $t \in[0, T]$ and all $x \in R^{n}$.

Theorem 1. Assume conditions (H1) and (H2) hold, and

$$
L=S\left(T M\left(1+T\left(\mu_{0}+\gamma_{0}\right)\right)+\sum_{i=1}^{p} l_{i}\right)<1
$$

where $S=\max _{[0, T] \times[0, T]}\|G(t, \tau)\|$.

Then boundary-value problem $(3)-(5)$ has a unique solution on $[0, T]$.

Proof. Transform the boundary value problem (3)-(5) into a fixed point problem. Consider the operator $F: P C\left([0, T] ; R^{n}\right) \rightarrow P C\left([0, T] ; R^{n}\right)$ defined by

$$
(F x)(t)=N^{-1} \alpha+\int_{0}^{T} G(t, \tau) f(\tau, x(\tau), \phi x(\tau), \varphi x(\tau)) d \tau+\sum_{0<t_{i}<T} G\left(t_{i}, t_{k}\right) I_{k}\left(x\left(t_{k}\right)\right) .
$$

Clearly, the fixed points of the operator $F$ are solutions of the boundary problem (3)-(5).

Setting $\max _{[0, T]}|f(t, 0,0,0)|=M_{f}, \max _{k \in\{1,2, \ldots, p\}}\left|I_{k}(0)\right|=m$ and let us select $r \geq \frac{\left\|N^{-1} \alpha\right\|+M_{f} T S+m p}{1-L}$. We show that $F B_{r} \subset B_{r}$, where

$$
B_{r}=\left\{x \in P C\left([0, T] R^{n}\right):\|x\| \leq r\right\} .
$$

For $x \in B_{r}$, using (H1) and (H2), we get

$$
\begin{aligned}
\|F x(t)\| \leq & \left\|N^{-1} \alpha\right\|+\int_{0}^{T}|G(t, \tau)|(|f(\tau, x(\tau), \phi x(\tau), \gamma x(\tau))-f(\tau, 0,0,0)|+|f(\tau, 0,0.0)|) d \tau \\
& +\sum_{k=1}^{p}\left|G\left(t_{i}, t_{k}\right)\right|\left(\left|I_{k}\left(x\left(t_{k}\right)\right)-I_{k}(0)\right|+\left|I_{k}(0)\right|\right) \\
\leq & \left\|N^{-1} d\right\|+S \int_{0}^{T}\left(M(|x|+|\phi x|+|\gamma x|)+M_{f}\right) d t+S \sum_{k=1}^{p} l_{k}\left|x\left(t_{k}\right)\right|+m p \\
\leq & \left\|N^{-1} d\right\|+S M T\left(|x|+T\left(\phi_{0}|x|\right)+\gamma_{0}|x|\right)+M_{f} T S+S \sum_{k=1}^{p} l_{k}|x|+m p \\
\leq & \left\|N^{-1} \alpha\right\|+S\left(M T\left(1+T\left(\phi_{0}+\gamma_{0}\right)\right)+\sum_{k=1}^{p} l_{k}\right)\|x\|+M_{f} T S+m p \leq r .
\end{aligned}
$$

In order to show that the operator $F$ is a contraction, let for any $x, y \in B_{r}$ we have

$$
\begin{aligned}
|F x-F y| \leq \int_{0}^{T} \mid G(t, \tau)(f(\tau, x(\tau), \phi x(t), \gamma x(t))-f(\tau, y(\tau), \phi y(t), \gamma x(t)) \mid d \tau & \\
& +\left|\sum_{k=1}^{p} G\left(t_{i}, t_{k}\right)\left(I_{k}\left(x\left(t_{k}\right)\right)-I_{k}\left(y\left(t_{k}\right)\right)\right)\right|
\end{aligned}
$$

Mathematics series. № 2(102)/2021 


$$
\begin{gathered}
\leq M S \int_{0}^{T}(|x(t)-y(t)|+|\phi x(t)-\phi y(t)+| \gamma x(t)-\gamma y(t)||) d t+S \sum_{k=1}^{p} l_{k}\left\|x\left(t_{k}\right)-y\left(t_{k}\right)\right\| \\
\leq S\left(M T\left(1+T\left(\phi_{0}+\gamma_{0}\right)\right)+\sum_{k=1}^{p} l_{k}\right) \max _{[0, T]}|x(t)-y(t)|
\end{gathered}
$$

or

$$
\|F x-F y\| \leq L\|x-y\| .
$$

It is seen that $F$ is contraction by condition (14). So the boundary-value problem (3)-(5) has a unique solution.

Theorem 2. Assume conditions (H1)-(H3) hold. Then boundary-value problem (3)-(5) has at least one solution on $[0, T]$.

Proof. Let $F$ be the operator defined in (15). We shall use Schaefer's fixed point theorem to prove that $F$ has a fixed point. The proof will be given in several steps.

Step 1:F is continuous. Let $\left\{x_{n}\right\}$ be a sequence such that $x_{n} \rightarrow x$ in $P C\left([0, T] ; R^{n}\right)$. Then, for each $t \in\left(t_{i}, t_{i+1}\right], i=0,1, \ldots, p$

$$
\begin{gathered}
\left|(F x)(t)-\left(F x_{n}\right)(t)\right|=\left|\int_{0}^{T} G(t, \tau)\left(f(\tau, x(\tau), \phi x(t), \gamma x(t))-f\left(\tau, x_{n}(\tau), \phi x_{n}(t), \gamma x_{n}(t)\right)\right) d \tau\right| \\
\quad+\left|\sum_{k=1}^{p} G\left(t_{i}, t_{k}\right)\left(I_{k}\left(x\left(t_{k}\right)\right)-I_{k}\left(x_{n}\left(t_{k}\right)\right)\right)\right| \\
\leq S\left(T M\left(1+T\left(\phi_{0}+\gamma_{0}\right)\right)+\sum_{k=1}^{p} l_{k}\right)\left|x(t)-x_{n}(t)\right| \leq L\left\|x-x_{n}\right\| .
\end{gathered}
$$

From here we get $\left\|(F x)(t)-\left(F x_{n}\right)(t)\right\| \rightarrow 0$ as $n \rightarrow \infty$, which implies that the operator $F$ is continuous.

Step 2: $F$ maps bounded sets into bounded sets in $P C\left([0, T] ; R^{n}\right)$. Indeed, it is enough to show that for any $\eta>0$ there exists a positive constant $\omega$ such that for each $x \in B_{\eta}=\left\{x \in P C\left([0, T] ; R^{n}\right):\|x\| \leq \eta\right\}$ we have $\|F(x)\| \leq \omega$. We have for each $t \in[0, T]$

$$
|(F x)(t)| \leq\left\|N^{-1} \alpha\right\|+S(T K+p k) .
$$

This implies that

$$
\|F(x)\| \leq\left\|N^{-1} \alpha\right\|+S(T K+p k)=\omega .
$$

Step 3: $F$ maps bounded sets into equicontinuous sets of $P C\left([0, T] ; R^{n}\right)$. Let $\xi_{1}, \xi_{2} \in[0, T], \xi_{1}<\xi_{2}, B_{\eta}$ be a bounded set of $P C\left([0, T] ; R^{n}\right)$ as in Step 2, and let $x \in B_{\eta}$.

Then, we have

$$
\begin{gathered}
F\left(x\left(\xi_{2}\right)\right)-F\left(x\left(\xi_{1}\right)\right) \\
=(A+B)^{-1} A \int_{0}^{\xi_{2}} f(\tau, x(\tau), \phi x(\tau), \gamma x(\tau)) d \tau-(A+B)^{-1} B \int_{\xi_{2}}^{T} f(\tau, x(\tau), \phi x(\tau), \gamma x(\tau)) d \tau \\
-(A+B)^{-1} A \int_{0}^{\xi_{1}} f(\tau, x(\tau), \phi x(\tau), \gamma x(\tau)) d \tau-(A+B)^{-1} B \int_{\xi_{1}}^{T} f(\tau, x(\tau), \phi x(\tau), \gamma x(\tau)) d \tau \\
=(A+B)^{-1} A \int_{\xi_{1}}^{\xi_{2}} f(\tau, x(\tau), \phi x(\tau), \gamma x(\tau)) d \tau+(A+B)^{-1} B \int_{\xi_{1}}^{\xi_{2}} f(\tau, x(\tau), \phi x(\tau), \gamma x(\tau)) d \tau \\
=\int_{\xi_{1}}^{\xi_{2}} f(\tau, x(\tau)) d \tau .
\end{gathered}
$$


As $t_{2} \rightarrow t_{1}$, the right-hand side of the above equalities tends to zero. As a consequence of Steps 1 to 3 together with the Ascoli-Arzela theorem, we can conclude that $F: P C\left([0, T] ; R^{n}\right) \rightarrow P C\left([0, T] ; R^{n}\right)$ is completely continuous.

Step 4: A priori bounds. Now it remains to show that the set $\Delta=\left\{x \in P C\left([0, T] ; R^{n}\right): x=\lambda F(x)\right.$ for some $0<\lambda<1\}$ is bounded. Let $x \in \Delta$. Then, $x=\lambda F(x)$ for some $0<\lambda<1$. Thus, for each $t \in\left(t_{i}, t_{i+1}\right] i=0,1, \ldots, p$, we have

$$
x(t)=\lambda N^{-1} \alpha+\lambda \int_{0}^{T} G(t, \tau) f(\tau, x(\tau), \phi x(\tau), \gamma x(\tau)) d \tau+\lambda \sum_{k=1}^{p} G\left(t_{i}, t_{k}\right) I_{k}\left(x\left(t_{k}\right)\right) .
$$

From here

$$
\|x\| \leq\left\|N^{-1} \alpha\right\|+S(T K+p k) .
$$

Therefore, the set $\Delta$ is bounded. The conclusion of Schaefer's fixed point theorem applies and the operator $F$ has at least one fixed point. So, there exists at least one solution for the problems $(3)-(5)$ on $[0, T]$.

\section{Example}

Consider the following system of integro-differential equations:

$$
\left\{\begin{array}{l}
\dot{x}_{1}=0.5 x_{2}+\sin \left(0.2 \int_{0}^{t} t s x_{1}(s) d s\right) \\
\dot{x}_{2}=0.5 x_{1}+\cos \left(0.2 \int_{0}^{1} t s x_{2}(s) d s\right)
\end{array}\right.
$$

with two-point boundary conditions

$$
x_{1}(0)=0, x_{2}(1)=1
$$

and impulsive condition

$$
\Delta x_{1}(0.5)=\frac{\left|x_{2}(0.5)\right|}{10\left(1+\left|x_{2}(0.5)\right|\right)}
$$

where $t \in[0,1], A=\left(\begin{array}{ll}1 & 0 \\ 0 & 0\end{array}\right), B=\left(\begin{array}{ll}0 & 0 \\ 0 & 1\end{array}\right)$ and $\mu(t, s)=\left(\begin{array}{cc}0.2 t s & 0 \\ 0 & 0\end{array}\right), \gamma(t, s)=\left(\begin{array}{cc}0 & 0 \\ 0 & 0.2 t s\end{array}\right)$, and $S=1, M=0.5, \mu_{0}=\gamma_{0}=0.2, l_{1}=0.1$.

Then $L=T S M\left(1+T\left(\mu_{0}+\gamma_{0}\right)\right)=0.5(1+0.2+0.2)+0.1=0.8<1$.

Thus, by Theorem 1 , the boundary value problem has a unique solution on $[0,1]$.

\section{Conclusion}

The boundary conditions considered in this paper are general enough and can be used extensively in a wide class of problems. In this article the existence and uniqueness of the solutions for the first-order nonlinear impulsive differential equations with two-point conditions are established under sufficient conditions. Note that the methods given here can be used in similar multi-point problems for the ordinary differential equations as follows:

$$
\dot{x}(t)=f(t, x(t), \mu x(t), \gamma x(t)), \quad t \in[0, T]
$$

with multi-point and integral boundary conditions

$$
\sum_{i=0}^{m} l_{i} x\left(t_{i}\right)+\int_{0}^{T} n(t) x(t) d t=\alpha
$$

Here $0=t_{0}<t_{1}<\ldots<t_{m-1}<t_{m}=T ; n(t) \in R^{n \times n}$ is a given function; $l_{i} \in R^{n \times n}, i=1,2, \ldots, m$ are given matrices; $\alpha \in R^{n}$ is a given vector and

$$
\operatorname{det} N \neq 0, N=\sum_{i=0}^{m} l_{i}+\int_{0}^{T} n(t) d t
$$




\section{References}

1 Benchohra M. Impulsive differential equations and inclusions / M. Benchohra, J. Henderson, S.K. Ntouyas. Contemporary Mathematics and Its Applications, Volume 2. - New York: Hindawi Publishing Corporation. $-2006 .-366$ p.

2 Boichuk A.A. Generalized inverse operators and Fredholm boundary-value problems / A.A Boichuk, A.M. Samoilenko. (2nd ed.) - Berlin/Boston: Walter de Gruyter GmbH. - 2016. - 314 p.

3 Boichuk A.A. Generalized Inverse Operators and Fredholm Boundary-Value Problems / A.A. Boichuk, A.M. Samoilenko. - Brill, Utrecht. - 2004.

4 Halanay A. Quality theory of impulse systems / A. Halanay, D. Wexler. - Moscow: Mir. $-1971 .-309$ p.

5 Lakshmikantham V. Theory of Impulsive Differential Equations / V. Lakshmikantham, D.D. Bainov, P.S. Simeonov. - Singapore: World Scientific. - 1989. - 434 p.

6 Perestyuk N.A. Differential equations with impulse effect: multivalued right-hand sides with discontinuities / N.A. Perestyuk, V.A. Plotnikov, A.M. Samoilenko, N.V. Skripnik. DeGruyter Stud. Math. - Berlin: Walter de Gruter Co. - 2011. - 40 p.

7 Samoilenko A.M. Impulsive differential equations / A.M. Samoilenko, N.A Perestyuk. - Kiev: Visha Sckola. $-1987 .-287 \mathrm{p}$.

8 Samoilenko A.M. Impulsive differential equations / A.M. Samoilenko, N.A. Perestyuk. - Singapore: World Sci. - 1995.

9 Mesloub S. On a mixed nonlinear one point boundary value problem for an integro-differential equation / S. Mesloub // Boundary Value Problems. - 2008. - Article ID 814947. - P. 1-8.

10 Anguraj A. Existence and uniqueness of mild and classical solutions of impulsive evolution equations / A. Anguraj, M. Mallika Arjunan // Electronic Journal of Differential Equations. - 2005. - 2005. No. 111. - P. 1-8.

11 Ashyralyev A. Existence and uniqueness of solutions for nonlinear impulsive differential equations with two-point and integral boundary conditions / A. Ashyralyev, Y.A. Sharifov // Advances in Difference Equations. - 2013. - 173. - P. 1-11.

$12 \mathrm{Li} \mathrm{M}$. Existence for neutral impulsive functional differential equations with nonlocal conditions / M. Li, M. Han // Indagationes Mathematicae. - 2009. - 20. - No. 3. - P. 435-451.

13 Mardanov M.J. Existence and Uniqueness of Solutions for the System of First-order Nonlinear Differential Equations with Three-point and Integral Boundary Conditions / M.J. Mardanov, Y.A. Sharifov, K.E. Ismayilova, S.A. Zamanova // European Journal of Pure and Applied Mathematics. - 2019. 12. - No. 3. - P. $756-770$.

14 Mardanov M.J. Existence and Uniqueness of Solutions for the First-Order Non-Linear Differential Equations with Three-Point Boundary Conditions / M.J. Mardanov, Y.A Sharifov, K. E. Ismayilova // Filomat. - 2019. - 33. - No. 5. - P. 1387-1395.

15 Mardanov M. J. Existence and uniqueness of the solutions to impulsive nonlinear integro-differential equations with nonlocal boundary conditions / M.J. Mardanov, Y.A Sharifov, F.M. Zeynalli // Proceedings of the Institute of Mathematics and Mechanics, National Academy of Sciences of Azerbaijan. - 2019. - 45. - No. 2. - P. 222-233.

16 Mardanov M.J. Existence and Uniqueness of Solutions for Nonlinear Impulsive Differential Equations with Three-Point and Integral Boundary Conditions / M.J. Mardanov, Y.A. Sharifov, R.A. Sardarova, H.N. Aliyev // Azerbaijan Journal of Mathematics. - 2020. - 10. - No. 1. - P. 110-126.

17 Mardanov M.J. Existence and uniqueness of solutions for the system of integro-differential equations with three-point and nonlinear integral boundary conditions / M.J. Mardanov, Y.A. Sharifov, K.E. Ismayilova // Bulletin of the Karaganda university-mathematics. - 2020. - 99. - No. 3. - P. 26-37.

18 Selvaraj B. Existence of solutions for impulsive nonlinear differential equations with nonlocal conditions / B. Selvaraj, M. Mallika Arjunan, V. Kavitha // J. KSIAM. - 2009. - 13. - No. 3. - P. 203-215.

19 Sharifov Y.A. Optimal control problem described by impulsive differential equations with nonlocal boundary conditions / Y.A. Sharifov, N.B. Mammadova // Differential equations. - 2014. - 50. - No. 3.P. 403-411.

20 Urabe M. An existence theorem for multi-point boundary value problems / M. Urabe // Funkcialaj Ekvacioj. - 1966. - 9. - P. 43-60. 
21 Abdullayev V.M. Numerical solution to optimal control problems with multipoint and integral conditions / V.M. Abdullayev // Proceedings of the Institute of Mathematics and Mechanics, National Academy of Sciences of Azerbaijan. - 2018. - 44. - No. 2. - P. 171-186.

22 Aida-zade K.R. An approach for solving nonlinearly loaded problems for linear ordinary differential equations / K.R. Aida-zade // Proceedings of the Institute of Mathematics and Mechanics, National Academy of Sciences of Azerbaijan. - 2018. - 44. - No. 2. - P. 338-350.

23 Самойленко А.М. Численно-аналитические методы исследования решения краевых задач / А.М. Самойленко, Н.И. Ронто. - Киев: Наук. думка, 1985. - 224 с.

24 Самойленко А.М. Численно-аналитические методы в теории краевых задач обыкновенных дифференциальных уравнений / А.М. Самойленко, Н.И. Ронто. - Киев: Наук. думка, 1992. - 279 с.

\footnotetext{
М.Дж. Марданов ${ }^{1,2}$, Р.С. Мамедов ${ }^{3}$, С.Ю. Касумов ${ }^{3}$, Я.А. Шарифов ${ }^{1,2}$

${ }^{1}$ Әзірбайжан Ұлттық, зылым академиясынын, Математика және механика институты, Баку, Әзірбайжан;

${ }^{2}$ Баку мемлекеттік университеті, Әзірбайжан;

3 Әзірбайжан мемлекеттік мұнай және өнеркәсіп университеті, Баку, Әзірбайжан
}

\title{
Екі нүктелі шекаралық шарттары бар бірінші ретті сызықты емес импульсті интегро-дифференциалдық теңдеулер үшін шешімнің бар және жалғыз болуы
}

\begin{abstract}
Мақалада импульстің әсерінен екі нүктелі шекаралық шарттары бар бірінші ретті сызықтыемес интегро-дифференциалдық теңдеулер жүйесінің шешімдерінің бар және жалғыз болуы талқыланды. Грин функциясы құрылды және қарастырылып отырған есепке эквивалентті интегралдық теңдеу келтірілді. Бұл есептің шешімінің бар және жалғыз болуы банахтың сығымдалған бейнелеуінің принципін қолдана отырып талданды. Қозғалмайтын нүкте туралы Шефер теоремасы шешімдердің бар екендігін дәлелдеу үшін қолданылды.
\end{abstract}

Kiлm сөздер: екі нүктелі шекаралық шарттар, импульстік жүйелер, шешімнің бар және жалғыз болуы, қозғалмайтын нүкте теоремалары, бірінші ретті дифференциалдық теңдеу.

М.Дж. Марданов ${ }^{1,2}$, Р.С. Мамедов ${ }^{3}$, С.Ю. Касумов ${ }^{3}$, Я.А. Шарифов ${ }^{1,2}$

${ }^{1}$ Институт математики и механики Начиональной академии наук Азербайджана, Баку, Азербайджан;

${ }^{2}$ Бакинский государственный университет, Азербайджан;

${ }^{3}$ Азербайджанский государственный университет нефти и промышленности, Баку, Азербайджан

\section{Существование и единственность результатов для нелинейных импульсных интегро-дифференциальных уравнений первого порядка с двухточечными граничными условиями}

\begin{abstract}
В статье обсуждены существование и единственность решений системы нелинейных интегро-дифференциальных уравнений первого порядка с двухточечными граничными условиями при импульсных воздействиях. Построена функция Грина, и рассматриваемая задача сведена к эквивалентному интегральному уравнению. Существование и единственность решения этой задачи проанализированы с помощью банахова принципа сжимающего отображения. Теорема Шефера о неподвижной точке использовалась для доказательства существования решений.
\end{abstract}

Ключевые слова: двухточечные граничные условия, импульсные системы, существование и единственность решения, теорема о неподвижной точке, дифференциальное уравнение первого порядка. 


\section{References}

1 Benchohra, M., Henderson, J., \& Ntouyas, S.K. (2006). Impulsive Differential Equations and Inclusions. New York: Hindawi Publishing Corporation.

2 Boichuk, A.A., \& Samoilenko, A.M. (2016). Generalized Inverse Operators and Fredholm Boundary-Value Problems. (2nd ed.) Walter de Gruyter GmbH, Berlin/Boston.

3 Boichuk, A.A., \& Samoilenko, A.M. (2004). Generalized Inverse Operators and Fredholm Boundary-Value Problems. Brill, Utrecht.

4 Halanay, A., \& Wexler, D. (1971). Quality Theory of Impulse Systems. Moscow: Mir.

5 Lakshmikantham, V., Bainov, D.D., \& Simeonov, P.S. (1989). Theory of Impulsive Differential Equations. Singapore: World Scientific.

6 Perestyuk, N.A., Plotnikov, V.A., Samoilenko, A.M., \& Skripnik, N.V. (2011). Differential Equations with Impulse Effect: Multivalued Right-Hand Sides with Discontinuities. DeGruyter Stud. Math., Walter de Gruter Co, Berlin.

7 Samoilenko, A.M., \& Perestyuk, N.A. (1987). Impulsive Differential Equations. Kiev: Visha Sckola.

8 Samoilenko, A.M., \& Perestyuk, N.A. (1995). Impulsive Differential Equation. Singapore: World Sci.

9 Mesloub, S. (2008). On a mixed nonlinear one point boundary value problem for an integro-differential equation. Boundary Value Problems, Article, ID 814947, 1-8.

10 Anguraj, A. \& Mallika Arjunan, M. (2005). Existence and uniqueness of mild and classical solutions of impulsive evolution equations. Elect. J. Differential Equations, 2005(111), 1-8.

11 Ashyralyev, A., \& Sharifov, Y.A. (2013). Existence and uniqueness of solutions for nonlinear impulsive differential equations with two-point and integral boundary conditions. Advances in Difference Equations, $2013(173), 1-11$.

12 Li, M., \& Han, M. (2009). Existence for neutral impulsive functional differential equations with nonlocal conditions. Indagationes Mathematicae, 20(3), 435-451.

13 Mardanov, M.J., Sharifov, Y.A., Ismayilova, K.E., \& Zamanova, S.A. (2019). Existence and uniqueness of solutions for the system of first-order nonlinear differential equations with three-point and integral boundary conditions. European Journal of Pure and Applied Mathematics, 12(3), 756-770.

14 Mardanov, M.J., Sharifov, Y.A., \& Ismayilova, K E. (2019). Existence and uniqueness of solutions for the first-order non-linear differential equations with three-point boundary conditions. Filomat, 33(5), $1387-1395$.

15 Mardanov, M.J., Sharifov, Y.A., \& Zeynalli, F.M. (2019). Existence and uniqueness of the solutions to impulsive nonlinear integro-differential equations with nonlocal boundary conditions. Proceedings of the Institute of Mathematics and Mechanics, National Academy of Sciences of Azerbaijan, 45(2), 222-233.

16 Mardanov, M.J., Sharifov, Y.A., Sardarova, R.A., \& Aliyev, H. N.(2020). Existence and uniqueness of solutions for nonlinear impulsive differential equations with three-point and integral boundary conditions. Azerbaijan Journal of Mathematics, 10(1), 110-126.

17 Mardanov, M.J., Sharifov, Y.A., \& Ismayilova, K.E. (2020). Existence and uniqueness of solutions for the system of integro-differential equations with three-point and nonlinear integral boundary conditions. Bulletin of the Karaganda University-mathematics, 99(3), 26-37.

18 Selvaraj, B., Mallika Arjunan, M., \& Kavitha, V. (2009). Existence of solutions for impulsive nonlinear differential equations with nonlocal conditions. J. KSIAM, 13(3), 203-215.

19 Sharifov, Y.A., \& Mammadova, N.B. (2014). Optimal control problem described by impulsive differential equations with nonlocal boundary conditions. Differential Equations, 50(3), 403-411.

20 Urabe, M. (1966). An existence theorem for multi-point boundary value problems. Funkcialaj Ekvacioj, 9, 43-60.

21 Abdullayev, V.M. (2018). Numerical solution to optimal control problems with multipoint and integral conditions. Proceedings of the Institute of Mathematics and Mechanics, National Academy of Sciences of Azerbaijan, 44(2), 171-186.

22 Aida-zade, K.R. (2018). An approach for solving nonlinearly loaded problems for linear ordinary differential equations. Proceedings of the Institute of Mathematics and Mechanics, National Academy of Sciences of Azerbaijan, 44(2), 338-350. 
23 Samoilenko, A.M., \& Ronto, N.I. (1985). Chislenno-analiticheskie metody issledovaniia resheniia kraevykh zadach [Numerical-Analytical Methods of Investigating Solutions of Boundary Value Problems]. Kiev: Naukova Dumka [in Russian].

24 Samoilenko, A.M., \& Ronto, N.I. (1992). Chislenno-analiticheskie metody v teorii kraevyh zadach obyknovennykh differentsialnykh uravnenii [Numerical-Analytical Methods in the Theory of Boundary Value Problems for Ordinary Differential Equations]. Kiev: Naukova Dumka [in Russian]. 